\title{
Desiccation of Pachira aquatica Aubl. Seeds
}

\author{
Amanda Araújo Lima ${ }^{1}$, Edilma Pereira Gonçalves ${ }^{2}$, Jeandson Silva Viana ${ }^{2}$, Priscila Cordeiro Souto ${ }^{3}$, \\ Débora Teresa da Rocha Gomes Ferreira ${ }^{2} \&$ Lidiana Nayara Ralph ${ }^{1}$ \\ ${ }^{1}$ Forestry Sciences, Rural Federal University of Pernambuco, Recife, Pernambuco, Brazil \\ ${ }^{2}$ Garanhuns Academic Unit, Rural Federal University of Pernambuco, Recife, Pernambuco, Brazil \\ ${ }^{3}$ Center for Agrarian Science, Federal University of Alagoas, Alagoas, Brazil \\ Correspondence: Débora Teresa da Rocha Gomes Ferreira, Garanhuns Academic Unit, Rural Federal University \\ of Pernambuco, Recife, Pernambuco, Brazil. E-mail: debora_teresa@hotmail.com
}

$\begin{array}{lcc}\text { Received: April 8, } 2018 & \text { Accepted: August 6, } 2018 & \text { Online Published: October 15, } 2018 \\ \text { doi:10.5539/jas.v10n11p553 } & \text { URL: https://doi.org/10.5539/jas.v10n11p553 }\end{array}$

\begin{abstract}
The conservation of seed quality during storage is important to perform the maintenance and conservation of germplasm banks. Several native species of Brazil are intolerant to desiccation to desirable levels for conservation during storage is necessary to develop specific technologies for their conservation. The objective of this research was to evaluate the physiological quality of Paquira aquatica seeds submitted to drying periods. The study was carried out using seeds of $P$. aquatica dried at a temperature of $35^{\circ} \mathrm{C}$, the following exposure times: 0 (no drying), 24, 48, 72 and 96 hours. Before and after each period of drying samples for the evaluations, the data were submitted to analysis of variance and regressionat level of 5\%. The seeds of $P$. aquatica were dispersed with very high water content and a small reduction in its physiological value agrees quality, allowing the seeds to characterize this as a recalcitrant species. The drying temperature is $35^{\circ} \mathrm{C}$ until the viable 24 hours after this period the water content of seed reduced from $55 \%$ to $43 \%$, which was considered the critical level for desiccation of seeds of P. aquatica. Because it reduces the values of first count, germination, rate of germination and growth of seedlings. The drying temperature the $35{ }^{\circ} \mathrm{C}$ until the viable 24 hours, whit small reduction in its physiological quality seed $P$. aquatica.
\end{abstract}

Keywords: conservation, drying seeds, viability, recalcitrant seed

\section{Introduction}

Pachira aquatica Aubl. is a native fruit tree from southern Mexico and northern Brazil, widely used in urban afforestation, may occur in wetlands and the distribution limit of mangroves but also in dry soils due to its adaptability in adverse climatic and soil conditions (Lorenzi et al., 2006; Lima et al., 2012; Infante-Mata et al., 2014). Its seeds have a high oil content, $46.62 \%$, and a significant amount of proteins, $13.75 \%$, typical characteristics of oleaginous species, and can be a good source for economic exploitation (Silva et al., 2010). The observed lipid content (46.62\%) in P. aquatica seeds was higher than that found in Glycine max L. (19.0-31.0\%) (Sharma et al., 2014; Sheykhbaglou et al., 2018) and Sterculia striata St Hil (23.9\%) seeds (Fráguas et al., 2015), and similar to that of the seed of Helianthus annuus L. (35.0-42.0\%) (Premnath et al., 2016) and Arachis hypogaea L. (44.0-56.0\%) (Kaya et al., 2009).

P. aquatica an excellent fount basis for developing well adapted and high yielding alternative oilseeds from the native flora for sustainable biodiesel production in Northeastern Brazil (Harand et al., 2016). This species is adaptable to the medium-sized, fast-growing crop and produces a large quantity of fruits with edible seeds with organoleptic characteristics (Jorge \& Luiza, 2012). However, its seeds are expenses with high moisture content, which makes it unfeasible to manage and store.

The seeds keep a constant exchange of moisture with the environment and therefore the water has great influence on their physiology. According to the physiological behavior during storage, seeds were generally classified into two distinct groups: orthodox and recalcitrant. The orthodox seeds, which are tolerant to desiccation, remain viable after desiccation to a water content of around 5\% and for this reason are more resistant when stored under low temperatures, and remain viable for a long period. However, the recalcitrant seeds, or seeds susceptible to desiccation, do not survive with low levels of humidity, which prevents their long-term storage. There are still 
seeds that have intermediate behavior, tolerating desiccation between 7 and $10 \%$ water content and do not withstand low temperatures during prolonged periods, whose behavior during drying and storage has similar characteristics to orthodox and recalcitrant (Roberts, 1973; Sarmento \& Villela, 2010; Costa, 2016).

The drying process of the seeds have two phases, which have no specific designation, giving one in sequence the other. The first phase happens in the movement of the water contained in the surface of the seed to the surrounding air, happening through the process of evaporation and being subject to the factors that control this process, the second phase consists of the passage of water from the internal tissues of the seed to the surface (Carvalho \& Nakagawa, 2012). This movement of the water molecules occurs by a process of capillarity and the mechanical obstacles in the way to be traveled by the molecules of water to the surface competes so that the second phase is slower than the first, also, as the seed dry, the drying becomes more time consuming (Carvalho, 2005).

At the time of dispersion, the recalcitrant seeds have a high water content, about 60 to $75 \%$ of their fresh weight, and practically do not lose water during maturation. When they are dehydrated after collection, there is a gradual loss of viability with drying, passing through a critical point until reaching the lethal water content, which is variable among the seeds of the different species, and there is no standard moisture content for drying of the seeds (Oliveira et al., 2011; Costa, 2016).

Identification the ideal desiccation period constitutes an important approachfor improve the conservation of recalcitrant seeds, and it is necessary to develop specific technologies for this purpose. In this way, the work was developed with the objective of evaluating the physiological quality of the seeds of $P$. aquatica submitted to drying periods.

\section{Material and Methods}

Theexperimentswas carried outon Laboratory of Seed Analysis (LSA) of the Universidade Federal Rural de Pernambuco/UnidadeAcadêmica de Garanhuns-PE.The fruits of Pachira aquatica Aubl. were collected with the aid of a trimmer five mother trees and captured through a mesh, preventing the fruit touched the ground. Then, the collected material was transported to the LAS, where the seeds were removed manually fruit and malformed and injuries were taken manually lot.

The experimental design was a completely randomized design with four replications of 25 seeds each treatment. The seeds of $P$. aquatica were homogenized, packed in paper bags and placed in an air circulation oven, regulated at $35^{\circ} \mathrm{C}$ for the following exposure periods: 0 (without drying), 24, 48, 72 and 96 hours. After each drying period was determined, the seed moisture content using four subsamples of five seeds for each treatment, and placed in a greenhouse at $105 \pm 3{ }^{\circ} \mathrm{C}$ for 24 hours, following the recommendations of Brasil (2009). Next the seeds were seeded in polyethylene trays with dimensions of $0.40 \times 0.30 \times 0.10 \mathrm{~m}$ in length, width and depth, respectively, containing as substrate washed sand, moistened with distilled water at $60 \%$ of the water retention capacity as recommended by Brasil (2009), with four replicates of 25 seeds, kept in the BOD (Biochemical Oxygen Demand) at $30{ }^{\circ} \mathrm{C}$ and photoperiod of 8 hours. Substrate moisture was maintained with addition of distilled water and the evaluations started on the eighth day ending on the 15th day after sowing, computing the seedlings that emitted the hypocotyl and the results were expressed as a percentage.

The germination speed index was conducted jointly with the germination test, accounting the number of seedlings that geminaram daily, and the germination speed index was calculated according to the formula proposed by Maguire (1962). At the end of the germination test, the roots and aerial part of normal each repetition seedlings were measured, with the aid of graduated ruler, and the results are expressed in $\mathrm{cm} \mathrm{pl-1.}$ After this determination, the roots and aerial part of seedlings of each replication were placed in paper bags and taken to the oven set at $80^{\circ} \mathrm{C}$ for 24 hours. After this period, were weighed on an analytical balance accurate to $0.001 \mathrm{~g}$, and the results are expressed in $\mathrm{g} \mathrm{pl}^{-1}$ (Nakagawa et al., 1999).

The data were submitted to analysis of variance and regression analysis were adjusted models polynomial linearat $5 \%$ of probability.

\section{Results}

The seed moisture content of Paquira aquatica seeds submitted to different drying periods at $35^{\circ} \mathrm{C}$ (Figure 1), the data were adjusted to the linear model, there being a reduction in the water content of the seeds with the increase of the drying periods.

At the beginning of the drying, the seeds of $P$. aquatica were with $59.95 \%$ water content.In the first 24 hours of drying, the reduction of humidity was slow, reducing the humidity in only $2.75 \%$ of water. With 48 hours of drying, the seeds had moisture loss of $11.79 \%$ in the water content, accounting for $48.19 \%$. After this period there was a stabilization in the water content and did not differ statistically between the other drying periods. 


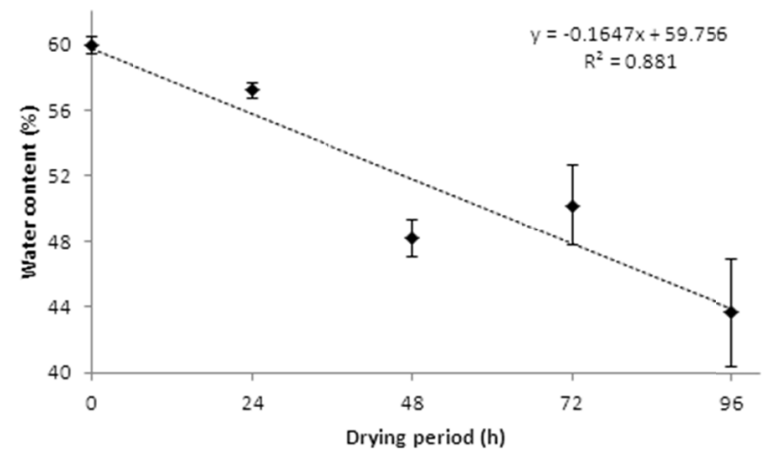

Figure 1. Water content of Pachira aquatica Aubl. submitted to drying periods.

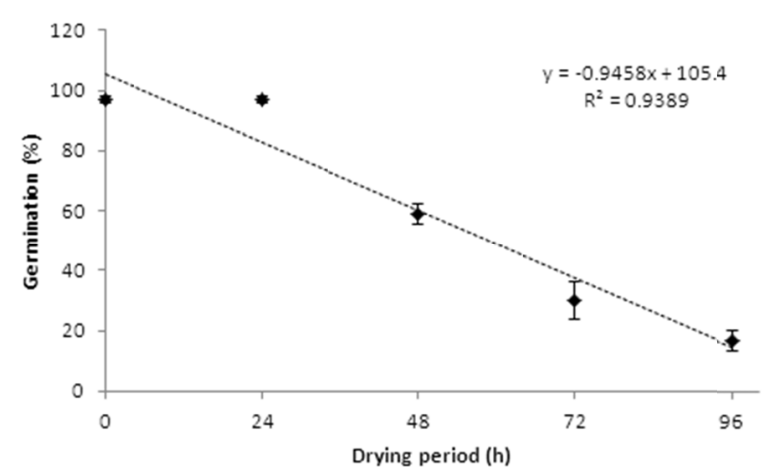

Figure 3. Germination of Pachira aquatica Aubl. seeds submitted to drying periods.

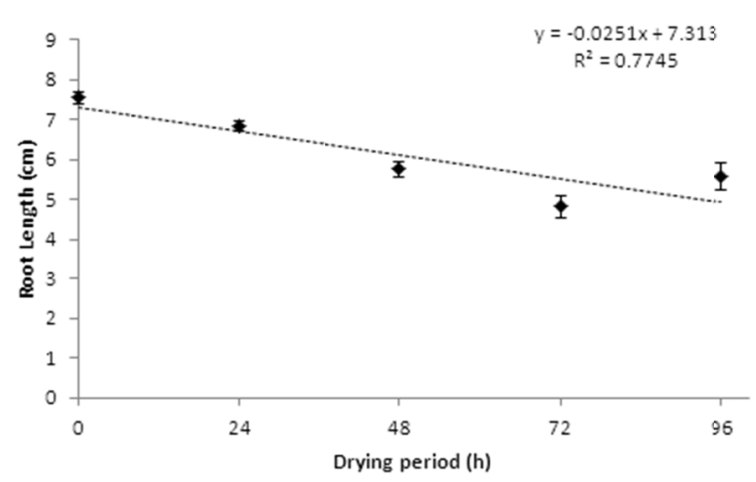

Figure 5. Root length primary of seedlings of Pachira aquatica Aubl. submitted to drying periods.

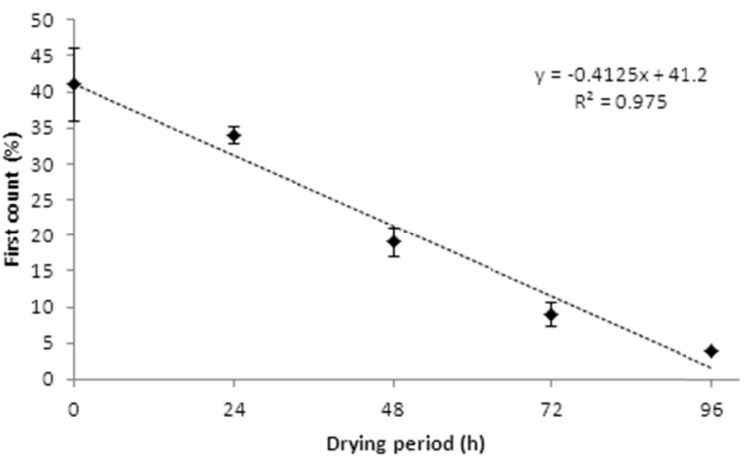

Figure 2. First count of germination of Pachira aquatica Aubl. seeds submitted to drying periods.

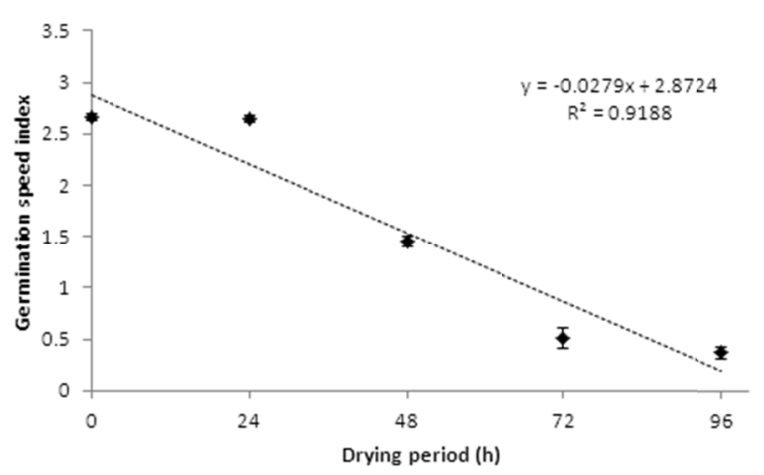

Figure 4. Germination speed index (IVG) of Pachira aquatica Aubl. seeds submitted to drying periods.

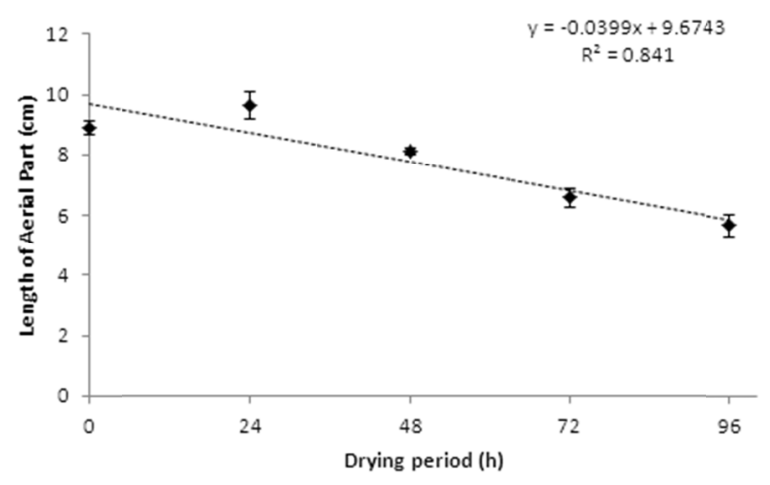

Figure 6. Length of aerial part of seedlings of Pachira aquatica Aubl. submitted to drying periods. 


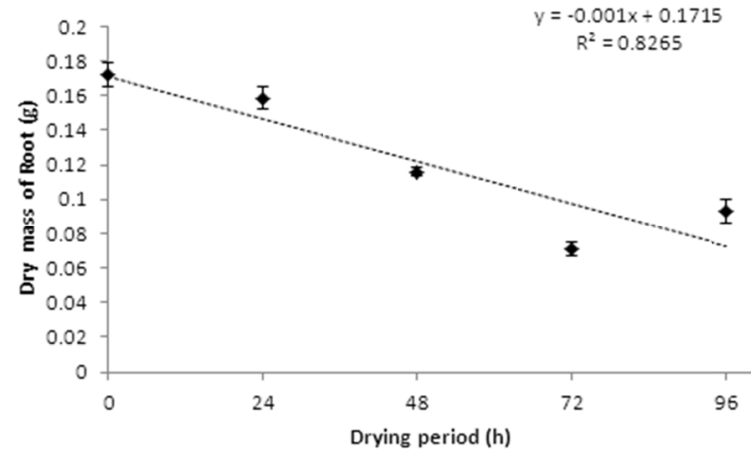

Figure 7. Dry mass of roots of seedlings Pachira aquatica Aubl. submitted to drying periods.

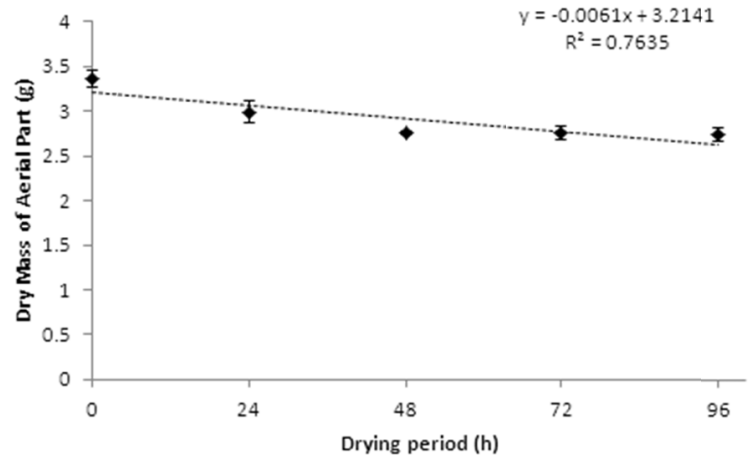

Figure 8. Dry mass of aerial part of seedlings Pachira aquatica Aubl. submitted to drying periods.

It was observed that the data of first count of germination where there was a drastic reduction from $41.00 \%$ at the beginning of the drying to $4 \%$ at the end of the 96 hours of drying (Figure 2).

The first germination count was affected with increasing drying time at $35^{\circ} \mathrm{C}$. At the zero time, the seeds of $P$. aquatica presented $43 \%$ of germination, reducing to $34 \%, 19 \%, 9 \%$ and $4 \%$ in the drying periods of $24,48,72$ and 96 hours, respectively. There was a reduction of $0.412 \%$ at each hour of drying, according to the linear adjustment equation.

The highest percentages of germination of Paquira aquatica seeds were observed in seeds that were not submitted to drying (zero hour period) and in the 24 hours period, both with $97 \%$ (Figure 3 ).

Seed germination was more affected in the drying periods of 48, 72 and 96 hours, with 59\%, 30\% and 17\%, respectively. There were no statistical differences in the water content of the seeds (Figure 1) and in the percentage of germination (Figure 3). However, was confirmed the germination decrease with the reduction of the water content of the seeds.

In relation to the germination speed index of $P$. aquatica seeds (Figure 4), it was observed that the seeds had a marked vigor loss and linear downward behavior, in other words, there was a reduction in the rate of germination with an increase in the periods of drying, with the highest index of 2.66 in the seeds that were not submitted to drying. As in the first germination count, the highest vigor was reached by the seeds that were not submitted to drying (zero hour period), starting to reduce after the 24 hours period, reaching 0.37 after 96 hours of drying.

The highest reductions in the germination speed index occurred in the last three drying periods, following the similar behavior of the variables water content, first count and germination.

In the initial development of the $P$. aquatica seedlings evaluated by the length of the primary root, it was observed a gradual reduction with the drying period of the seeds. The seeds not submitted to drying reached the maximum length was $7.54 \mathrm{~cm}$, followed by the drying treatment for 24 hours with $6.85 \mathrm{~cm}$ and the lowest of $4.84 \mathrm{~cm}$ in the period of 72 hours of drying (Figure 5).

This vigor test, together with the first germination count test and the germination speed index, showed that the physiological quality of the seeds was impaired after the first 24 hours of drying, reducing their viability due to the loss of water.

For the length of the aerial part of the seedlings (Figure 6), the reduction in the length of the aerial part of the seeds was verified, with a maximum length of $9.65 \mathrm{~cm}$, reducing with the increase of the drying periods, with a smaller length of $5.64 \mathrm{~cm}$ in the 96 hours period.

The aerial part growth from seedling originating of the seeds submitted to drying for 24 hours was the highest of the treatments studied, presenting a value of $9.65 \mathrm{~cm}$ in height. The lowest development of aerial part was verified in seedlings originating from the seeds at 72 hours of drying with $6.54 \mathrm{~cm}$ and $5.63 \mathrm{~cm}$ of height with 96 hours of drying.

Regarding the mass of the roots of the seedlings (Figure 7), the greatest accumulation of dry mass was verified in the seeds that were not submitted to drying, with 0.1724 .

The root dry mass of the seedlings was reduced with the increase of the drying period, showing a linear regression model with $\mathrm{R}^{2}$ of $82.6 \%$ and a reduction in the dry mass of $0.001 \mathrm{~g}$ per hour of drying seeds. In the 
first 24 hours of drying, root dry mass did not show statistical difference between the two treatments, with a dry mass of $0.172 \mathrm{~g}$ of root in the treatment without drying ( 0 hours) and $0.158 \mathrm{~g}$ with 24 hours of drying. However, when the seeds were submitted to the drying period longer than 48 hours, the root dry mass accumulation reduced to $0.115 \mathrm{~g}$ in 48 hours, $0.071 \mathrm{~g}$ in 72 hours and $0.092 \mathrm{~g}$ in 96 hours of drying.

Drying of the seeds of $P$. aquatica affected the accumulation of dry mass of the aerial part of the seedlings. The highest accumulation of dry mass of aerial part $3.36 \mathrm{~g}$, was found in the seedlings from the seeds with the highest water content, without drying. The second best accumulation was found in the 24 hours drying treatment with $2.99 \mathrm{~g}$, the seeds submmited to dried for 48, 72 and 96 hours did not present statistical difference in the aerial part dry mass (Figure 8), following the same behavior observed in the water content of the seeds (Figure 1).

Seed deterioration caused by the dehydration of the seeds affected the germination and vigor, making the germination slower and decreasing the growth of the seedlings. The drying P. aquatica seeds, probably, caused damage to vital seed tissues, such as the embryo, which would explain the reduction of germination and seed vigor after 48 hours drying.

\section{Discussion}

The seeds of $P$. aquatica presents $59.9 \%$ of water in the harvest period after reaching the physiological maturity, being considered high water content (Stubsgaard, 1990). However, it is known that during the development of most recalcitrant seeds there is no decline in water content and consequently they have intense metabolic activity. One of the characteristics of the recalcitrant seeds is to have a high water content at the time of dispersion, because unlike the orthodox seeds, the recalcitrant seeds do not undergo a thorough desiccation process during maturation and/or predating the dispersion (Santos-Moura et al., 2012).

The recalcitrant seeds are not only independent of the drying process to acquire the germinative capacity, but also present limits of desiccation tolerance (Barbedo \& Marcos Filho, 1998). The water content limit of the seeds of $P$. aquatica was $50.2 \%$, below this value the germination and vigor were affected.

In addition to the water content, the dehydration speed of the recalcitrant seeds may affect the physiological potentials of the seeds. During the first 24 hours, the seeds of $P$. aquatica presented slow water loss, with no great loss in their physiological quality. After 48 hours of drying, the loss of water was more severe and fast resulting in a greater reduction in germination and vigor. According to Delgado and Barbedo (2007) the drying speed is considered fundamental for the evaluation of the tolerance limit to the desiccation of the seeds. The fast loss of water by the seeds causes severe damage to the membrane structure of the cell organelles, the cytoskeleton and the skeletal nucleus that are essential for the proper functioning of the cell and damage to these structures during drying may lead to loss of viability of the seeds (Berjak \& Pammanter, 2003).

This reduction in the germination and vigor of the seeds of $P$. aquatica shows that the reduction of the water content negatively affects the physiological quality of the seeds, allowing to classify the seeds of this species as recalcitrant. The water loss in recalcitrant seeds triggers some deteriorating processes, such as protein denaturation, changes in the activity of peroxidase enzymes and damage to the membrane system, resulting in the complete loss of viability (Soares et al., 2015). Unbalanced metabolism and damage due to dehydration are the main causes of loss of viability of seeds during drying (Berjak \& Pammennter, 2003). Thus, loss of water during the dehydration phase, the loss of seed volume itself, can result in structural mechanical damage that may not be corrected during rehydration in the germination process.

Pammenter and Berjak (2000) point out two types of damages that occur in recalcitrant seeds when subjected to drying: macromolecule-related damages and damages resulting from the maintenance of seeds at intermediate levels of water, leading to oxidative stress as a consequence of a deregulated metabolism, with this the seeds remain several days with a high content of humidity. In recalcitrant seeds, the subcellular water is strongly associated with the macromolecular surfaces, ensuring, in part, the stability of membranes and macromolecules (Bovi et al., 2004). Thus, the loss of structural water during the drying process of recalcitrant seeds can cause severe changes in the metabolic and membrane systems, leading to the deterioration process of these seeds (Angelovici et al., 2010).

The activity of the enzymes present in lipid-rich seeds increases rapidly with the onset of germination, reaching peak when lipid degradation and carbohydrate synthesis are at their peak, resulting in rapid deterioration of the seed by the peroxidation process of lipids, resulting in reduction in the dry matter of the seedlings (Angelovici et al., 2010; Costa, 2016). 
The increase of the respiratory activities of the seed to a level capable of sustaining the growth of the embryo, with sufficient supply of energy and organic substances, depends on the increase of the degree of hydration of its tissues (Popinigis, 1985). The increase in respiratory rate, due to the high water content, results in the reduction of the speed of reconstruction of the membranes during imbibition and in degenerative changes in the metabolism of the seeds, triggered by the destructuring and loss of the integrity of the cellular membranes system caused especially for the degradation of the tissues of reserves that would be used in the germination of the seeds (Marcos Filho, 2005). Thus, the energy reserve that would be used in the germination is spent in the respiration, causing less weight transfer of the dry matter weight of the cotyledons to the embryonic axis of the seed, giving rise to a seedling with lower dry mass.

The reduction of the water content affected the vigor of the seeds of Paquira aquatica, demonstrating that they are sensitive to desiccation, and drying after the 24 hours period compromises the physiological quality of the seeds.

Seeds of other arboreal species, classified as recalcitrant, presented the same behavior. The initial water content of the seeds of Bunchosia armenia (Cav.) DC. was $62.6 \%$, reducing to 43.3 and $32.1 \%$ after 120 hours of drying in a laboratory environment and greenhouse, respectively (Silva et al., 2012). In drying conditions, the seeds of Blepharocalyxs alicifolius and Casearia decandra were sensitive to moisture reduction between $29 \%$ and $25 \%$ and lost viability around $14 \%$ and $8 \%$ of humidity, respectively, in relation to physiological changes during drying of the seeds, it was observed a decrease of viability and vigor from $25 \%$ of humidity (Rego et al., 2013).

Santos-Moura et al. (2012) verified that the drying at $40{ }^{\circ} \mathrm{C}$ of the seeds of Tapirira guianensisAubl. reduced in the first germination count, the maximum percentages $(62 \%)$ occurred in the seeds that were not dehydrated (zero hour of drying), not being verified germination from the 12 hours of drying, noting that the reduction of the water content affected negatively the vigor, determined by the first germination count, as observed for the seeds of $P$. aquatica.

Seeds of Theobroma subincanum tolerate a reduction in water content, without compromising the germinative power, only up to a level around 30\% (Nascimento \& Carvalho, 2012). However, Barrozo et al. (2014) verified that the percentage of germination in seeds of Inga laurina (Sw.) Willd. presented maximum germination values (99\%) after 16 hours, at which time the seeds were still with the water content around $46.52 \%$. Drying at $30{ }^{\circ} \mathrm{C}$ of the seeds of Campomanesia pubescens (DC.) O. Berg., Dousseau et al. (2011) observed that the water content of the seeds extracted from the fruits was $42 \%$, which was reduced exponentially as a result of drying, reaching $4 \%$ moisture at 810 minutes, classifying them as recalcitrant seeds because they were intolerant to drying.

The drying of the seeds of $P$. aquatica at $35^{\circ} \mathrm{C}$ affected the length of the aerial part of the root of the seedlings, because the loss of water caused damage to the embryo reserves, those that would be unfolded and transported to the embryonic axis, aiding in their growth. According to Oliveira et al. (2011) the energetic reserves destined for the growth of the seedlings is compromised in the drying process due to the deterioration of the seeds during the process, which would explain the reduction of the length of the aerial part verified in this work with the increase of the periods of drying. Laime et al. (2011) observed the highest lengths of seedlings of Inga ingoides (Rich.) Willd., $12 \mathrm{~cm}$ of root and $8,5 \mathrm{~cm}$ of aerial part were obtained when the water content of the seeds of $47 \%$, with a drastic reduction of the length of seedlings after desiccation of the seeds.

The dry mass of the Inga ingoides seedlings was also influenced by periods of exposure to drying (Laime et al., 2011). It was identified by Scalon et al. (2012) than for the seeds of Eugenia pyriformis Camb. there was a significant negative interference in the first count, percentage of germination, dry mass and length of shoot and root of seedlings, reflecting in lower values as the seeds of this species were submitted to the dehydration process, being the effects more noticeable from $30 \%$ humidity.

Results those found by Alves et al. (2008) in seeds of Talisia esculenta (A. St. Hil) Radlk, they observed that prolonged periods of drying caused harmful physiological effects on dry mass of seedlings.

Drying of the seeds of $P$. aquatica at $35^{\circ} \mathrm{C}$ after 24 hours had harmful effects on the vigor of the seeds, proving their sensitivity to desiccation, since prolonged periods of drying caused deleterious effects to the germination and vigor of the seeds. The desiccation tolerance is directly related to the environment in which the seeds develop (Nascimento et al., 2007). Tolerant species to desiccation are able to survive with reduced values of cellular water for long periods (Buitink, 2000). Species under study are recommended for recovery of riparian forest because spontaneously the tree vegetates in humid places, riverbanks and lakes or flooded lands, where the word "aquatic" comes from its scientific name, this may justify the behavior of its seeds drying. 


\section{Conclusion}

Seeds of the species Paquira aquatica Aubl. are dispersed with very high water content, and a small reduction in this value compromises their physiological quality, allowing to characterize the seeds of this species as recalcitrant. Drying at $35^{\circ} \mathrm{C}$ is feasible for up to 24 hours, after that period the water content is reduced affecting germination and vigor of the seeds.

\section{References}

Alves, E. U., Silva, K. B., Bruno, R. L. A., Alves, A. U., Cardoso, E. A., Gonçalves, E. P., \& Braz, M. S. S. (2008). Comportamento fisiológico de sementes de pitombeira [Talisia esculenta (A. ST. Hil) Radlk] submetidas à desidratação. Revista Brasileira de Fruticultura, 30, 509-516. https://doi.org/10.1590/ S0100-29452008000200042

Angelovici, R., Galili, G., Fernie, A. R., \& Fait, A. (2010). Seeddesiccation: A bridge between maturation and germination. Trends in Plant Science, 15(4), 211-218. https://doi.org/10.1016/ j.tplants.2010.01.003

Barbedo, C. J., \& Marcos-Filho, J. (1998). Tolerância à dessecação de sementes. Acta BotanicaBrasilica, 12, 145-164.

Barrozo, L. M., Alves, E. U., Araújo, L. R., Sena, D. V. A., Medeiros, D. S., \& Santos, J. C. (2014). Qualidade fisiológica de sementes de ingá em função da secagem. Bioscience Journal, 30, 645-654.

Berjak, P., \& Pammenter, N. W. (2003). Orthodox and recalcitrant seeds. In J. A. Vozzo (Ed.), Tropical tree seed manual (pp. 137-147). Washington: USDA Forest Science.

Bovi, M. L. A., Martins, C. C., \& Spiering, S. H. (2004). Desidratação de sementes de quatro lotes de pupunheira: Efeitos sobre a germinação e o vigor. Horticultura Brasileira, 22, 109-112. https://doi.org/10.1590/ S0102-05362004000100023

Brasil. (2009). Ministério da Agricultura, Pecuária e Abastecimento. Regras para análise de sementes (p. 395). Brasília: Secretaria de Defesa Agropecuária.

Buitink, J., Hoekstra, F. A., \& Hemminga, M. A. (2000). A critical assessment of the role of oligosaccharides in intracellular glass stability. In M. Black, K. J. Bradford, \& J. Vasques-Ramos (Eds.), Seed Biology: Advances and Applications (pp. 461-466). Wallingford, UK: CAB International. https://doi.org/10.1079/9780851994 048.0461

Carvalho, N. M. (2005). A secagem de sementes (2nd ed., p. 184). Jaboticabal: FUNEP.

Carvalho, N. M., \& Nakagawa, J. (2012). Sementes-Ciência, Tecnologia e Produção (5th ed., p. 590). Jaboticabal: Funep. https://doi.org/10.1590/S0101-20612012005000073

Costa, M. C. D. (2016). Desiccation tolerance in seeds and plants (p. 184, $\mathrm{PhD}$ thesis, Wageningen University, Wageningen, NL).

Delgado, L. F., \& Barbedo, C. J. (2007). Tolerância à dessecação de sementes de espécies de Eugenia. Pesq. Agropec. Bras., Brasilia, 42(2), 265-272. https://doi.org/10.1590/S0100-204X2007000200016

Dousseau, S., Alvarenga, A. A., Guimarães, R. M., Lara, T. S., Custódio, T. N., \& Chaves, I. S. (2011). Ecofísiologia da germinação de sementes de Campomanesia pubescens. Ciência Rural, 41, 1362-1368. https://doi.org/10.1590/S0103-84782011000800011

Fráguas, R. M., Simão, A. A., Lima, R. A. D., Rocha, D. A., Queiroz, E. D. R., Braga, M. A., ... Patto de Abreu, C. M. (2015). Chemical constituents of chichá (Sterculia striata St. Hil. etNaud.) seeds. African Journal of Agricultural Research, 10(9), 965-969. https://doi.org/10.5897/AJAR2014.9235

Harand, W., Pinho, R. S., \& Felix, L. P. (2016). Alternative oilseeds for Northeastern Brazil: Unrevealed potential of Brazilian biodiversity. Brazilian Journal of Botany, 39, 169-183. https://doi.org/10.1007/s40415 $-015-0233-\mathrm{z}$

Infante-Mata, D., Moreno-Casasola, P., \& Madero-Vega, C. (2014). Pachira aquatica, un indicador dellímitedelmanglar? Revista Mexicana de Biodiversidad, 85, 143-160. https://doi.org/10.7550/rmb.32656

Jorge, N., \& Luzia, D. M. M. (2012). Caracterização do óleo das sementes de Pachira aquatica Aublet para aproveitamento alimentar. Acta Amazonica, 42(1), 149-156. https://doi.org/10.1590/S0044-5967201200 0100017 
Kaya, C., Hamamci, C., Baysal, A., Akba, O., Erdogan, S., \& Saydut, A. (2009). Methyl ester of peanut (Arachis hypogea L.) seed oil as a potential feedstock for biodiesel production. Renewable Energy, 34, 1257-1260. https://doi.org/10.1016/j.renene.2008.10.002

Laime, E. M. O., Oliveira, D. C. S., \& Alves, R. S. G. (2011). Emergência e crescimento inicial de plântulas de Ingaingoides (Rich.) Willd. em função da secagem das sementes. Engenharia Ambiental, 8, 237-250.

Lima, M. F. D., Miranda, D. P., \& Karsburg, I. V. (2012). Caracterização dos cromossomos de Pachira aquatica Aubl. (Malvaceae). Revista Estudos, 39, 337-343.

Lorenzi, H., Sartori, S., Bacher, L. B., \& Lacerda, M. (2006). Frutas brasileiras e exóticas cultivadas: De consumo in natura (p. 61). São Paulo: InstitutoPlantarum de Estudos da Flora.

Maguire, J. D. (1962). Speed of germination-aid in selection and evaluation for seedling emergence and vigor. Crop Science, 2, 176-177. https://doi.org/10.2135/cropsci1962.0011183X000200020033x

Marcos-Filho, J. (2005). Fisiologia de sementes de plantas cultivadas (p. 495). Piracicaba: Fealq.

Nakagawa, J., Krzyzanoswki, F. C., Vieira, R. D., \& França-Neto, J. B. (1999). Testes de vigor baseados no desempenho das plântulas. Vigor de sementes: Conceitos e testes (pp. 2.1-2.24). Londrina: ABRATES.

Nascimento, W. M. O., \& Carvalho, J. E. U. (2012). Sensibilidade de sementes de cupuí (Theobromasu bincanum) à redução do grau de umidade e a exposição à baixa temperatura. Revista Brasileira de Fruticultura, 34, 915-920. https://doi.org/10.1590/S0100-29452012000300034

Nascimento, W. M. O., Novembre, A. D. L. C., \& Cicero, S. M. (2007). Conseqüências fisiológicas da dessecação em sementes de açaí (Euterpe oleracea Mart.). Rev. Bras. Sementes, 29(2), 38-43. https://doi.org/10.1590/S0101-31222007000200006

Oliveira, J. T. A., Vasconcelos, I. M., Bezerra, L. C. N. M., Silveira, S. B., Monteiro, A. C. O., \& Moreira, R. A. (2000). Composition and nutritional properties of seeds Pachira aquatica Aubl, Sterculia striata StHil et Naud and Terminalia catappa Linn. Food Chemistry, 70, 185-191. https://doi.org/10.1016/S0308-8146 (00)00076-5

Oliveira, L. M., Silva, E. O., Bruno, R. L. A., \& Alves, E. U. (2011). Períodos e ambientes de secagem na qualidade de sementes de Genipa americana L. Semina: Ciências Agrárias, 32, 495-502. https://doi.org/10.5433/1679-0359.2011v32n2p495

Pammenter, N. W., \& Berjak, P. (2000). Aspects of recalcitrant seed physiology. Revista Brasileira de Fisiologia Vegetal, 12, 56-69.

Popinigis, F. (1985). Fisiologia da semente (5th ed., p. 289). Brasília, Brazil.

Premnath, A., Narayana, M., Ramakrishnan, C., Kuppusamy, S., \& Chockalingam, V. (2016). Mapping quantitative trait loci controlling oil content, oleic acid and linoleic acid content in sunflower (Helianthus annuиs L.). Mol Breed, 36(7), 1-7. https://doi.org/10.1007/s11032-016-0527-2

Rego, S. S., Nogueira, A. C., Medeiros, A. C. S., Petkowicz, C. L. O., \& Santos, A. F. (2013). Physiological behaviour of Blepharocalyxsalicifoliusand Caseariadecandraseeds on the tolerance to dehydration. Journal of Seed Science, 35, 323-330. https://doi.org/10.1590/S2317-15372013000300008

Roberts, E. H. (1973). Predicting the storage life of seeds. Seed Science and Technology, 1, 499-514.

Santos-Moura, S. S., Alves, E. U., Bruno, R. L., Moura, M. F., \& Gondim, P. S. S. (2012). Influência de diferentes períodos de secagem na qualidade fisiológica de sementes de Tapiriraguianensis Aublet. Revista Brasileira de Fruticultura, 34, 382-390. https://doi.org/10.1590/S0100-29452012000200010

Sarmento, M. B., \& Villela, F. A. (2010). Sementes de espécies florestais nativas do sul do Brasil. Informativo ABRATES, 20, 39-44.

Scalon, S. P. Q., Neves, S. E. M., Maseto, T. E., \& Pereira, Z. V. (2012). Sensibilidade à dessecação e ao armazenamento em sementes de Eugenia pyriformis Cambess. (uvaia). Revista Brasileira de Fruticultura, 34, 269-276. https://doi.org/10.1590/S0100-29452012000100036

Sharma, S., Kaur, M., Goyal, R., \& Gill, B. S. (2014). Physical characteristics and nutritional composition of some new soybean (Glycine max (L.) Merrill) genotypes. Journal of Food Science and Technology, 51(3), 551-557. https://doi.org/10.1007/s13197-011-0517-7 
Sheykhbaglou, R., Sedghi, M., \& Fathi-Achachlouie, B. (2018). The Effect of Ferrous Nano-oxide Particles on Physiological Traits and Nutritional Compounds of Soybean (Glycine max L.) Seed. Anais da Academia Brasileira de Ciências, 90(1), 485-494. https://doi.org/10.1590/0001-3765201820160251

Silva, B. L. A., Azevedo, C. C., \& Azevedo, F. L. A. A. (2015). Propriedades funcionais das proteínas de amêndoas da munguba (Pachira aquatica Aubl.) Revista Brasileira Fruticultura, 37, 193-200. https://doi.org/10.1590/0100-2945-065/14

Silva, B. L. A., Bora, O. S., \& Azevedo, C. C. (2010). Caracterização química parcial das Proteínas das Amêndoas da Munguba (Pachira aquatic Aubl). Revista Instituto Adolfo Lutz, 69, 333-340.

Silva, K. B., Alves, E. U., Matos, V. P., \& Bruno, R. L. A. (2012). Caracterização morfológica de frutos, sementes e fases da germinação de Pachira aquatica Aubl. (Bombacaceae). Semina: Ciências Agrárias, 33, 891-898. https://doi.org/10.5433/1679-0359.2012v33n3p891

Soares, G. C. M., Dias, D. C. F. S., Faria, J. M. R., Borges, E. E. L. (2015). Physiological and biochemical changes during the loss of desiccation tolerance in germinating Adenantherapavonina L. seeds. Anais da Academia Brasileira de Ciências, 87(4), 2001-2011. https://doi.org/10.1590/0001-3765201520140195

Stubsgaard, F. (1990). Seed moisture (p. 30). Humlebaek: DFSC.

\section{Copyrights}

Copyright for this article is retained by the author(s), with first publication rights granted to the journal.

This is an open-access article distributed under the terms and conditions of the Creative Commons Attribution license (http://creativecommons.org/licenses/by/4.0/). 